\title{
PRACTICAL PROBLEMS CONCERNING THE INTRODUCTION OF A NEW LEGAL INSTITUTION - TORT IN HUNGARIAN CIVIL LAW
}

\section{PRAKTICKÉ PROBLÉMY TÝKAJÚCEHO SA UVEDENIA NOVÉHO PRÁVNEHO INŠTITÚTU - DELICT V MAĎARSKOM SÚKROMNOM PRÁVE}

\author{
László Pribula \\ University of Debrecen, Faculty of Law \\ https://doi.org/10.33542/SIC2019-1-09
}

\begin{abstract}
The new Hungarian Civil Code which came into effect on March 15, 2014, introduced-instead of the earlier non-material compensation - a new legal institution, namely the tort. The tort is the general subjective sanction of personality right offences. However, it is not clear whether this new legal institution shall function as a modern remedy in personality rights protection; or simply the former judicial practice of non-pecuniary damages will continue. After all, the near future will answer the question whether tort meets the expectations pronounced by the legislator.
\end{abstract}

\begin{abstract}
ABSTRAKT
Nový mad'arský civilný zákonník, ktorý nadobudol účinnost' dňa 15. marca 2014, zaviedol namiesto doterajšej nemateriálnej náhrady - nový právny inštitút, a to súkromný delikt. Súkromný delikt je všeobecná subjektívna sankcia porušenia osobných práv. Avšak, nie je jednoznačné, či tento nový právny inštitút bude fungovat' ako moderný prostriedok v ochrane osobných práv; alebo jednoducho predchádzajúca súdna prax nepeňažnej náhrady škody bude pokračovat. Nasledujúce obdobie však dá odpoved' na otázku, či súkromný delict spĺña očakávania, ktoré sú predstávané zákonodárcom.
\end{abstract}

\section{CONCEPTUAL CHANGES IN THE NEW HUNGARIAN CIVIL CODE}

Hungarian legislation introduced a new civil substantial code on 15 March, 2014, namely Act V of 2013 on the Civil Code. The new code replaced the earlier Civil Code, Act IV of 1959, which was passed and in effect in the socialist era. The new civil code aims to effectuate a categorically different aspect, as its ideal is the independent person who is responsible for their own decisions. According to Hungarian authors several conceptual changes have been made. ${ }^{1}$ The new civil substantial code now includes family law and the laws concerning business associations which were formerly regulated separately, the base for responsibility is divided between violation of contract and damages caused beyond the contract, and the legislator also introduced new types of contracts such as franchise, leasing, or confidential trusteeship, which

SZIKORA, Veronika: Az új magyar Polgári Törvénykönyv kodifikációjának föbb állomásai (The process of the codification of the new Hungarian Civil Code) In: Erik Štenpien (ed.): Kúpna Zmluva - História a súcasnost: Univerzita Pavla Jozefa . Košice: Terra Recognita Foundation; Univerzita Pavla Jozefa Safárika v Kosiciach, 2013. pp. 338-356. 
had previously been practised but not regulated. Basically, however, it elevated the well-functioning judiciary interpretative practice on the level of law. The new civil code has been generally praised by legal literature, as it is seen as an up-to-date, professionally high-standard code which adapted to the changing social and economic circumstances. ${ }^{2}$

Besides numerous novelties, the new Civil Code introduced an interesting, by far unknown legal institution in Hungarian history of law, that is, the general subjective sanction of personality right offences, namely the tort. As tort can be applied as the subjective legal consequence for personality right offences committed only after the effectuation of the Civil Code, we still have not had a wide application practice resulting from this short period, however, the practical issues of the new institution can be observed and analysed.

The tools for a financial compensation for personality right offences show a wide range of variety in different legal systems. As Tamás Lábady characterised it, laws concerning non-material compensation are extremely complicated, nevertheless, chaotic, often in certain state laws, both from historical and comparative aspects. Certain legal solutions are unclear, both dogmatically and terminologically. ${ }^{3}$ Hungarian regulation shows a very similar picture.

\section{NON-MATERIAL COMPENSATION IN LEGISLATION}

The regulations of Hungarian civil law did not know about the opportunity of sanctioning personality right offences for a long period. Although Press Law already included non-material compensation for certain press law offences in 1914, the socialist interpretation considered personality a basically ethical entity, consequently offence against the personality could not be converted into money. Consequently, in 1952 the Presidential Council of Ministers countermanded those conceptual decisions which concerned compensation for non-material damage, and then Civil Conceptual Decision III also eliminated this legal institution. Judiciary practice meant to compensate damages to personality right by invoking the so-called general compensation, which could be justified only in exceptional cases, and which could be applied only in cases when the damage was definitely provable, but the extent of which could not be stated even after careful evidence. Eventually, in Act IV of 1977 (coming into effect on 1 March, 1978), the legislator introduced the institution of non-material compensation. The base for judgement is extremely limited by the law, as non-material compensation may be judged in cases when the damage to the personality resulted in a severe and permanent impairment, so in practice it is applied mostly in cases of death or corporal injuries resulting in impairment. After the change of the political regime, however, the Constitutional Court countermanded the legal regulation concerning the restrictive conditions for non-material compensation, but the judiciary practice could not yet leave the detriment-focused judgement behind. The chief message of the Constitutional Court decision was exactly that the emphasis should not be laid on the severity of the detriment as the aim of non-material compensation is not only reparation, but also prevention, and the latter function of non-material compensation cannot prevail if the offence resulting in not obviously provable detriments is not sanctioned with compensation.

The former Civil Code did not in any way regulate the conditions and applicability of nonmaterial compensation after the Constitutional Court decision, the only result of the translatives of the law was that this institution exists as part of the damage, but the question could not be

2 Interview with Professor Lajos Vékás http://jogaszvilag.hu/rovatok/szakma/vekas-lajos-az-uj-ptk-hibai-ellenere-is-sikertortenet (09.06.2013.), Interview with Professor Tamás Sárközy http://ptk2013.hu/interjuk/a-jogi-szemelyek-szabalyozasaaz-uj-ptk-ban-interju-sarkozy-tamas-professzorral/912 (14.11.2012.)

3 LÁBADY, Tamás: Sérelemdij versus nem vagyoni kártérités (Tort vs. non-material compensation). Állam-és Jogtudomány 2016.1., p.40. 
answered whether non-material compensation was pronouncedly a sanction for only the violation of personality rights, or offences of different nature; whether the conditions were limited for the damage or separately from it either severe or inconsiderable detriment resulting in the damage; or what the factors determined the amount of compensation for an immaterial, financially non-measurable injuria. Resulting in the flexible regulation created by the legislator, these issues laid upon constitutional court and jurisdictional practice. Beyond this, the law also included the institution of fine of public interest, which could have been judged according to the former Civil Code, if the fine for compensation would not have been proportionate to the severity of the offence, and it was not the offended party who was entitled to the amount but the state, rightly fulfilling the objectives of the punishment.

During the codification of the civil code, the introduction of an institution emerged which is conceptually separated from compensation: it is not based on the division of material and nonmaterial damages which are considered with similar aspects, but on the assumption that the damage and the offence of personality rights must be separated. In the former case material sanction can be applied if the asset was damaged as a result of the offending behaviour, may it be either a decrease in its value, any unfulfilled advantage, or costs emerged, while the offence of personality right would automatically call for material compensation, consequently it is not necessary to prove the further detriments beyond the fact of the offence.

Tort, introduced instead of non-material compensation, is assessed exclusively as a sanction for personality right offence already based on the locus of the regulation. Furthermore, the legislator determined the conditions of its application in detail. Paragraphs 1 to 3 of Article 2:52 of the new Civil Code command that the person who is offended in their personality right can claim tort for the non-material damage, the regulations concerning liability for damages must be applied as the conditions for the tort - especially the definition of the person who pays the tort and the means of bailout. It is not necessary to prove the detriment beyond the fact of the offence to be entitled to the tort, and the degree of the tort is determined by the judiciary in one amount according to the circumstances of the case, especially to the severity and the persistency of the offence, the extent of imputability, the effect of the offence on the offended and their relations.

\section{NON-MATERIAL COMPENSATION IN JURISDICTION}

In the history of law the procedure is unique as a result of which, following the change of the political regime, Hungarian law application essentially restructured the formerly non-material compensation that the new institution did not land on a terra incognita, but the new civil substantial code took over the already well-founded judiciary practice.

After the Constitutional Court countermanded the strict applicability conditions of non-material compensation, which were defined as permanent and severe drawbacks in life circumstances, judiciary practice could not leave behind the fixated ways of judgements that the condition of non-material compensation is a form of estimable, possibly severe detriment.

Non-material damages cannot practically be exchanged to money, thus one cannot compensate for them in the strict sense. As Melinda Mátyás put it, immaterial damage is practically fictitious, given that damage here is no more than an offence of personality right. Personality right offences do not have their financial equivalents. These detriments are irreparable. This fact makes this legal institution so ambiguous that law itself is not a sufficient tool to make it sturdy, as the degree of the damage cannot be objectively stated, it is defined by the judiciary's consideration. ${ }^{4}$ Law application concerning personality right offences under the effect of the

4 MÁTYÁS, Melinda: A nem vagyoni kártérités elméleti alapjai (The theoretical ground of non-material compensation). Debreceni Jogi Mühely online review, 2009. 1. of October 
former civil code did not satisfy in constantly emphasising that it is basically impossible to determine objective aspects for everyone when determining the amount of non-material compensation, but rather made an effort deliberately to create a uniform law application, that is, to determine the circumstances in a unified way to ground the common degree of compensation. However, as Endre Tamás Tóth characterised these difficulties, as a result of the incorporeality of compensation and the undefinable nature of the damage, our legal system does not include tariff rules in terms of certain damaged rights in typical cases, not even as guidelines. ${ }^{5}$

According to the former civil code, the necessary condition of liability for damages - also for non-material damages - was the occurrence of the damage, related to the offensive behaviour. However, for a longer period, law application was uncertain about the interpretation of personality right offences whether they can be interpreted as damages, or there must be some kind of other, related non-material damage. The first related professional opinion was expressed by the Civil and Administrative College of the Court of Baranya County on 17 November, 2000, claiming that the necessary, irremissible, but not exclusive condition of judging nonmaterial compensation is the statement of the offence of a certain personality's right, to apply the sanction, more statements of fact are needed. Later judiciary practice justified several judgements by stating that it can be supposed as well-known that certain defined damages to personality right cause non-material detriment. ${ }^{6}$ Although judiciary law application refused to identify the concepts of material damage and personality right damage, but instead frequently emphasised that substantial law does not regulate non-material compensation as tort, but, based on general life experience, was ready to assume that offending personal rights can affect the offended as the offended experiences the offence as a negative effect, and does not expect any more itemised evidence. The offended considers unlawful detention, death of a relative, or the unconsented use of their portrait as offences based on which no further evidence of detriment than the fact of the offence is necessary for the assertion of their right to non-material compensation. The modern-age development of non-material compensation has reached a level where the judiciary, invoking the substantial institution called facts of public knowledge, brought the concepts of offence and detriment closer, and has far left behind the outdated interpretation which would have demanded evidence for some kind of - even severe - damage in health, mind, life conduct, relationship in family, job, or friendship or of any other nature as a result of the personality right offence. The continuous changes in judiciary practice had adapted to the general protection of personality right well before the effectuation of the new civil code, and was suitable to exclude compensation as the unconditional result of offences of minor severity, thus averting the frivolity of the institution.

\section{TORT AS THE "SUCCESSOR" OF NON-MATERIAL COMPENSATION?}

In her thorough analysis of the development of Hungarian subjective personality right sanctions, Ágnes Enikő Béky valued the - previously in its present form unknown - institution of tort, which replaced non-material compensation, outstandingly significant, also adding that the conversion from the present detriment-centred judgement to tort is expected to be difficult. ${ }^{7}$ As Ádám Fuglinszky pointed out in his detailed analysis, although tort replaced non-material compensation, tort is not compensation ${ }^{8}$, as it is not the "successor" of non-material compensation.

On the one hand tort does not only differ from non-material compensation in omitting detriment from the conditions, but also another legal institution was built in its framework, namely

CSÉCSY, Andrea - FÉZER, Tamás - HAVASI, Péter - TÓTH, Endre Tamás - VARGA, Nelli: A kártéritési jog magyarázata (The interpretation of compensation law). Complex Kiadó Kft. -Budapest 2010., p. 312.

6 Court of Appeal, Budapest 7.Pf.21.213/2010/6., Court of Appeal, Debrecen Pf.I.20.690/2009/5.

7 BÉKY, Ágnes Enikő: A személyiségvédelem aktuális kérdései (Recent issues of personality right protection). Debreceni Jogi Mühely online review 2007. április 1.

8 FUGLINSZKY, Ádám: Kártéritési jog (Compensation Law) HVG-ORAC Kiadó Kft., Budapest 2015., p 829. 
the practically not applied fine of public interest. This institution thus becomes a special solution as from among the elements of the previous non-material compensation personality right offence takes over financial compensation which adapts to the damage caused, meanwhile it aims to establish the punitive private law material sanction - on behalf of the state and not the offended party - which adapts to the severity, frequency and the limit of culpability.

According to the previous solution, non-material compensation and fine of public interest were not consequently related, as the suitable reparation on punishment characteristics were not divided, since the application of non-material compensation was defined as the prerequisite of the fine. In theory the two institutions could have functioned independently from each other, since between the detriment caused by the damage and the offensive behaviour there is no direct correlation, so only fine could have been imposed, in case there was no detriment. This hypothesis remains merely theoretical because judiciary practice did not impose fine of public interest, regarding primarily the entitled, namely the state.

It is also interesting to mention that according to the original idea (still relevant at the time of the 2003 passing of the concept of the new civil code) tort would not have replaced nonmaterial compensation but the fine of public interest. In the sense of the dualistic version, alongside with non-material compensation regulated in its previous form, there would have been the opportunity to impose tort if the sum of the non-material compensation would not have adjusted to the severity of the offence. But in this case the entitled would have been the offended party, and not the state. Similarly, the legislator was determined to sanction all personality right offences materially, even offences without damages.

Later drafts and the materialised regulation decided on the monist solution, and the institutions of non-material compensation and tort were fused in a special way. Created this way, and non-existing previously in Hungarian law, tort simultaneously considers the severity of the offence (punitive trait) and the effect of the offence on the offended (compensational trait).

\section{PUNITIVE DAMAGES}

Lawsuits including the application of tort have raised some crucial questions which has to be examined based on the judgements and a stand has to be taken.

One of these questions is whether the function of the so-called "punishment of private law" should be taken into account when appointing the sum of tort. The experts' proposal to the new civil code wished to introduce tort as the efficient sanction to protect personality rights with a primary function of compensating offence with a material recompense, and only secondarily as a private law punishment. However, the passed law did not differentiate the two functions when it declared that the judiciary has to consider the severity and frequency of the offence, the extent of imputability, and the impact of the offence on the offended and their relations. Lajos Vékás, head of the Codification Chief Committee highlighted in his study before passing the law what must be avoided, that judiciary practice must not effectuate the punitive element and must not diverge into the direction of a kind of punitive damages. ${ }^{9}$

The development of law in recent years justified compensation for damages to personality right on the basis of the extent of the damages caused by the offence. When determining the sum of non-material compensation, the reparative function was the exclusive aspect, referring to detrimental changes in the corporal, mental, and social-natural environment of the personality, but avoided to consider the severity of the offence or its social judgement, based on the prevalence of the preventive function, as aspects of criminal law are far from civil law judgement. As a result of this opinion judiciary practice did not judge fine of public interest because

9 VÉKÁS, Lajos: Bírálat és jobbitó észrevételek az új Ptk. kormányjavaslatához (Critique and amendments to the government proposal of the new Civil Code). Magyar Jog 2013.1., p. 4. 
of its earlier punitive function. However, above non-material compensation, the legislator also included the punitive but on the other hand preventive sanction into tort which falls to the offended party's share, thus challenging judiciary practice again.

Hungarian law application has to consider the change that the compensational aspect aims to judge such a sum on behalf of the offended party which is approximately sufficient to restore - at least approximately - the original situation, that is, to create the - even ideal - condition, as if the offence had not taken place. From this aspect it is basically devious to allot the damaged person of the offence to financial payments above the sum sufficient for the compensation of the damage just because, on the basis of other circumstances, it is justified to "punish" the offender. By this act co-ordination, characteristic of civil law, and the balance of rights and duties would turn over.

Since the introduction of tort, there are still judgements in Hungarian judiciary practice which emphasise the reparative function of tort and aim to compensate the damages.

A judgement by the Court of Appeal, Budapest found it justified to oblige the appellee to pay a tort of HUF 70.000 to each claimant in a lawsuit for the use of voice recordings made without consent. The reasoning of the judgment highlighted that apart from stating the fact of offence no other condition must be fulfilled to be entitled to the tort, thus all the necessary lawful conditions hold true for the validation of personality protection. For the determination of degree of the tort, consideration must be applied to determine the sum of the tort, measuring the weight of the offence and the damages of the offended. As for the degree, one can state that for the offended it must include such a sum which serves to compensate the claimant's damage as a detriment in connection with the unconsented voice recording. Tort is a tool which serves to eliminate prejudice on the aggrieved party's side. The judgement-at-law would have expected more proved evidence for a higher sum above the facts of common knowledge as for the use of unconsented voice recording, which could have proved the disadvantageous alteration in the advantageous social position of the claimants. The Court judged the lower sum without these, based on the disadvantages of common knowledge. ${ }^{10}$

Another judgement of the Court of Appeal, Budapest obliged the correctional institution as the appellee of the lawsuit to pay a tort of HUF 150.000 to compensate the injury of the convicted claimant, who injured the back of the hand when, getting of his bunk bed using a stool as no secure ladder was supplied, and the stool tipped over. The judgement-at-law highlighted that the sum of the tort was determined according to the degree of the damage. In this case, the claimant's hand was hardly usable for two weeks, and for another one month only in limited extent, which caused a setback in their everyday life, thus injuring their personality right to physical integrity, consequently the appellee is obliged to the pay the tort determined in the judgement-at-law. The further aspects of the sum of the tort were not mentioned in the judgement-at-law. ${ }^{11}$

On the other hand, however, judgements have already been made which included the private law punitive function. The Court of Appeal, Debrecen judged a tort of HUF 100.000 for misjudging an electric wheelchair for an electric moped and not letting it on a scheduled local bus, since electric mopeds are not allowed on local buses. The physically disabled claimant claimed compensation because he was refused to get on the local bus with his electric wheelchair, after which he used the local tram nearby. The reasoning of the judgement emphasised that the institution of tort is essentially applied for damages caused by any offensive behaviour against personality rights which can be stated by common knowledge without any other necessary evidence, and which can be compensated for by casting the appellee in costs, while at the same

10 Court of Appeal, Budapest 17.Pf.21.101/2015/8-II.

11 Court of Appeal, Budapest 9.Pf.20.491/2016/5-II. 
time the offensive behaviour can be sanctioned above it, with regard to the circumstances defined by the law, as it also has a private punitive function. When determining the costs, the judgement considered that the impact of the personality right offence on the offended person was of low importance and of short, temporary term, the established damage were the temporary humiliation and the necessity of surplus action to pass to the nearby tram stop. The judgement also appraised that behind the discrimination of the claimant there were neither deliberateness, nor any other conscious motivation, the act was the result of an honest, undeliberate mistake. It also weighed the fact that although the evidence of the lawsuit showed that the appellee had already acted offensively earlier with the claimant, thus formally the offence is repetitive, but since the earlier offence nearly four years had passed, and the repetitive character can be taken into consideration only in a minor extent. ${ }^{12}$

In connection to the tort, it is going to be a challenge for judiciary practice whether for the determination of the costs the same aspects have to be taken into consideration as in the case of non-material compensation, or as a result of evaluating the punitive function, with the same damages the costs of the tort are going to be higher than the non-material compensation under the effect of the 1959 Civil Code, if it is justified by the severity and frequency of the offence, the extent of imputability and the impact of the offence on the environment of the offended.

This question was examined by the collegial meeting of the Court of Appeal, Debrecen on 9 and 10 March, 2017. At the meeting most of the speakers argued that it should be avoided that judiciary practice emphasise the punitive element, the starting point should be basically the compensative function, and primarily the degree of the damage should be taken into consideration.

\section{NOMINAL DAMAGES}

Another important interpretational issue was whether a claim may be dismissed on the basis that despite a personality right offence realised, the damage of the offended cannot be established, not even as a fact of common knowledge.

Since the introduction of tort the discussion is continuous both in literature and among practicing lawyers, whether the unnecessity to prove the damages results in an automatically judged tort if the personality right offence realised.

The reasoning of Decision 1/2013. (VI. 17) of the Civil College of the Court of Appeal, Budapest on certain questions of the judgement of non-material compensation/tort in civil lawsuits expressly pointed out that courts have to find other aspects to filter out bagatelle cases, as persons claiming tort do not need to prove the damage in the future.

It is obvious that one cannot support the misuse of tort. There has been several proposals in literature how to avoid it. One of these ideas is to judge a symbolic tort, which is definitely smaller that the costs of the lawsuit, even 1 forint (HUF 1, for which there is no change in Hungarian currency) for minor offences, hoping that on the long run the spread of such a judiciary practice unfounded claims for tort will be suppressed. ${ }^{13}$ Another proposal would call the newly introduced predictability clause of compensation law, according to which the causative correlation between the behaviour and the resulting damage cannot be established if the offender could not foresee any consequence of the minor-weight behaviour which could justify the application of tort. ${ }^{14}$ The third idea would have limited the concept of personality right

Court of Appeal, Debrecen Pf.1.20.956/2016/6.

Presentation of Tamás LÁBADY at the law conference on the effecuation of the new Civil Code on 18 March, 2014.

14 ANKA, Tibor - FABÓ, Tibor - FAZEKAS, Judit - FUGLINSZKY, Ádám - HARSÁNYI, Györgyi - MENYHÁRD, Attila - OROSZ, Árpád - TŐKEY, Balázs - VILLÁM, Krisztián: A Polgári Törvénykönyvröl szóló 2013. évi V. törvény és a kapcsolódó jogszabályok nagykommentárja IV. (Commentary of the Hungarian Civil Code IV.), Opten Informatikai Kft. 2014., pp. 66-67. 
offence by excluding formally offensive behaviours causing minor damage or no damage at all with the double filter of the major offence clause, according to which the judiciary examines primarily whether based on general experience if the offence is capable of causing any kind of damage to the personality, secondarily declares whether the offensive behaviour could have a damaging impact on the given personality to justify tort. Either the primary or the secondary consideration resulting in a negative answer excludes a determination of an even symbolic sum of tort. ${ }^{15}$

The question seems to be finalised in Hungarian judiciary practice. Since the introduction of tort, there has been made judgements-at-law which established the personality right offence but refused the claim for tort reasoning that tort was introduced to substantial law because the legislator meant to reach a reasonable aim. Such an aim can be the termination of a damaging situation, reparation, retorsion, or holding back from similar offences. If because of the circumstances of the behaviour to be sanctioned neither supportable aim can be reached, since in the cases of bagatelle damages no prevention can be expected, the legislator does not mean to express disapproval and there is no situation to be repaired, then it is unnecessary to apply the sanction. ${ }^{16}$

One of the important appeal judgements of the Curia emphasised that the view is false according to which the exclusive condition of judging tort is the establishment of offence, and the judiciary cannot consider whether the application of the sanctions amends the damages of the person involved or the offender should also be obliged to pay a tort, besides these legal consequences. A judgement refused the claim for tort of a political party for a false statement uttered in front of some private persons in a private talk, including information about bribing certain persons to vote for their candidates with minor sums. The judgement reasoned that establishing the offence does not automatically consequences application of tort. Although the entitled person does not have to prove the damage according to the new regulation, it is not a precondition of judging a tort. On the other hand, the person involved can claim tort for a non-material damage. The function of tort is to compensate for non-material damages caused by offending personality rights. The new Civil Code prescribes for the courts the consideration of all the circumstances to judge a tort and to determine the costs, also declaring what aspects the acting court has to consider in the given case to consider whether the tort is necessary and justified or not. When determining the sum of the tort, the following aspects are of significance: the damage and its severity, degree, frequency, the extent of imputability, the impact of the offence on the offended and their environment. The court has to establish the damages to the person involved by considering all these aspects and decide whether the person is entitled to the tort, and if they are, to what sum. The judge's consideration may lead in certain cases lead to the situation that the offender cannot be obliged to paying tort, because the application of the imposed objective sanctions is a suitable and sufficient tool to amend the damage. ${ }^{17}$

The standpoint of the forming judiciary practice is that when a personality right offence is realised but causes only insignificant damage, the claim for tort can be dismissed. The Counselling Body of the "New Civil Code" established by the chairman of the Curia announced the same viewpoint, stating that besides establishing the personality right offence and judging the objective sanctions, the court may dismiss the claim for tort if the offended was not affected by a non-material damage which could serve as the basis for tort. The regulation of the law releases the claimant from the substantial obligation to prove the damage, but for lack of non-material damage it does not make it possible to claim for tort. The aims of the regulations which ensure the opportunity to cast the offender to a tort are best suited by those judgements which do not

15 FÉZER, Tamás: A bagatell igények kiszürése a személyiségi jogi perekben (Filtering bagatelle claims in personality right lawsuits). ugyvedvilag.hu online review 01.06.2013.

16 Court of Appeal, Debrecen Pf.I.20.387/2015/3. and Pf.I.20.240/2015/4.

17 Curia Pfv.IV.21.764/2015/4. 
cast anyone to such a low cost that is unsuitable either to compensate for the damage, or to exert a preventive effect. ${ }^{18}$

\section{SUMMARY}

The introduction of tort was a giant leap in Hungarian law history, as general financial sanction for the protection of personality rights appeared on the level of law without supposing the proof of the damage. The introduction of a new legal institution always means a challenge for the courts, so the near future will answer the question whether tort came up to the expectations pronounced by the legislator.

\section{KEYWORDS}

Hungarian Civil Code, tort, personality rights

\section{KLUUČOVÉ SLOVÁ}

Mad’arský civilný zákonník, súkromný delikt, osobné práva

\section{BIBLIOGRAPHY}

1. ANKA, Tibor-FABÓ, Tibor-FAZEKAS, Judit-FUGLINSZKY, Ádám-HARSÁNYI, Györgyi - MENYHÁRD, Attila - OROSZ, Árpád - TÖKEY, Balázs - VILLÁM, Krisztián: Commentary of the Hungarian Civil Code IV., Opten Informatikai Kft. 2014, 836 p.

2. BÉKY, Ágnes Enikö: Recent issues of personality right protection, Debreceni Jogi Mühely online review, 1 of April, 2007.

3. CSÉCSY, Andrea - FÉZER, Tamás - HAVASI, Péter - TÓTH, Endre Tamás - VARGA, Nelli: The interpretation of compensation law, Complex Kiadó Kft. -Budapest 2010., 453 p.

4. FÉZER, Tamás: Filtering bagatelle claims in personality right lawsuits, ugyvedvilag.hu online review, 01.06.2013.

5. FUGLINSZKY, Ádám: Compensation Law, HVG-ORAC Kiadó Kft., Budapest 2015., $904 \mathrm{p}$.

6. LÁBADY, Tamás: Tort vs. non-material compensation, Állam-és Jogtudomány 2016.1, pp. 40-45.

7. MÁTYÁS, Melinda: The theoretical ground of non-material compensation, Debreceni Jogi Mühely online review, 2009. 1. of October

8. SZIKORA, Veronika: The process of the codification of the new Hungarian Civil Code In: Erik Štenpien (ed.): Kúpna Zmluva - História a súcasnost: Univerzita Pavla Jozefa . Košice: Terra Recognita Foundation; Univerzita Pavla Jozefa Safárika v Kosiciach, 2013. pp. 338-356.

9. VÉKÁS, Lajos: Critique and amendments to the government proposal of the new Civil Code, Magyar Jog 2013.1., pp. 1-7.

10. Interview with Professor Tamás Sárközy http://ptk2013.hu/interjuk/a-jogi-szemelyek-szabalyozasa-az-uj-ptk-ban-interju-sarkozy-tamas-professzorral/912 (14.11.2012.)

11. Interview with Professor Lajos Vékás http://jogaszvilag.hu/rovatok/szakma/vekas-lajosaz-uj-ptk-hibai-ellenere-is-sikertortenet (09.06.2013.),

12. Presentation of Tamás LÁBADY at the law conference on the effecuation of the new Civil Code on 18 March, 2014.

\footnotetext{
18 http://kuria-birosag.hu/hu/ptk?\&body value=\&page=1 (25.03.2017).
} 


\section{CONTACT DETAILS OF AUTHOR}

Dr. László Pribula

associate professor

Head of Civil Procedure Law Department

University of Debrecen, Faculty of Law

E: pribula.laszlo@law.unideb.hu 